\title{
Sawn Timber and Rotary Veneer Processing and Grade Recovery Investigation of Northern Australian Plantation Grown African Mahogany
}

\author{
Robert L. McGavin,, a,b,* John McGrath, ${ }^{\mathrm{c}, \mathrm{d}}$ Chris Fitzgerald, ${ }^{\mathrm{a}}$ Chandan Kumar, \\ Chris Oliver, ${ }^{\mathrm{e}}$ and Alex Lindsay ${ }^{\mathrm{f}}$
}

\begin{abstract}
Over half of the large African mahogany plantation estate in northern Australia has reached the mid-point of the target rotation length of 20 to 25 years. As such, there is increasing interest in understanding the potential volume and grade qualities recovered from these young trees using different processing methods. The objective of this study was to compare the recovery rates and product grade quality for rotary veneer using spindleless lathe technology and sawn boards using traditional sawing techniques. Net veneer recovery ranged between $42 \%$ and $55 \%$ of log volume, with most veneers being limited to D-grade. Compression, surface roughness, and grain breakout were the most prominent defects limiting veneer grade. The sawn-dried-dressed recovery was low, with less than $20 \%$ of the log volume representing a potential saleable product. The small log diameter combined with defects including wane, heart shake, pith, and knots reduced the potential recovery. A high presence of sawn board distortion was observed that negatively impacted the efficiency of sawn timber processing along with product recovery. While low, the recovery of veneers and sawn timber from young African mahogany was like other young plantation grown hardwoods.
\end{abstract}

Keywords: African mahogany; Plantation; Sawn timber; Rotary veneer; Recovery; Grade quality

Contact information: a: Queensland Department of Agriculture and Fisheries, Horticulture and Forestry Science, Salisbury Research Facility, 50 Evans Rd., Salisbury, Queensland 4107 Australia; b: School of Civil Engineering, The University of Queensland, St. Lucia, Queensland 4072 Australia; c: McGrath Forestry Services, 13 Zenith Street, Shelley Western Australia 6148 Australia; d: Murdoch University, Murdoch Western Australia 6150 Australia; e: African Mahogany Australia, P.O. Box 615 Nightcliff NT 0814 Australia; f: Forsite Forestry, P.O. Box 350, Innisfail, Queensland 4860 Australia;

*Corresponding author: robbie.mcgavin@daf.qld.gov.au

\section{INTRODUCTION}

African mahogany (Khaya senegalensis) has an international reputation as being an important forest tree species that can produce high-value timber. Native to the seasonally dry belt from Senegal-Guinea to Sudan-Uganda, early trials in northern Australia dating back to the 1960s demonstrated strong potential for the species to be established in plantations (Reilly et al. 2014). Industrial plantation establishment commenced in the Northern Territory, Australia in 2006 with the estate now at around 14,000 hectares. A plantation estate of around 1,000 hectares exists in North Queensland, Australia. While some genetic selection was undertaken, the Australian African mahogany plantations were essentially established with unimproved mixed seed lots. These plantations have been established primarily to grow sawlogs from which high-quality and high-value sawn timber is expected. 
Numerous research activities have been undertaken to support the Australian African mahogany industry, with the majority focused on genetic improvement, and plantation establishment and management (Nikles 2006; Reilly et al. 2007; Nikles et al. 2008; Dickinson et al. 2009). Research on wood properties, processing strategies, and target products has been limited. Both Zbonak et al. (2010) and Armstrong et al. (2007) reported valuable baseline information on wood properties, sawn timber qualities, and sawn recoveries of Australian grown African mahogany. Zbonak et al. (2010) reported limited rotary veneer grade and recovery information. However, both studies were conducted on a limited number of logs and were sourced from plantations that potentially do not represent the growth and form expected from trees from industrial plantations due to the different growing conditions.

With some of the industrial plantations in Australia now considered to be post midrotation, there is increasing interest in identifying suitable processing systems and target markets for material resulting from both mid-rotation thinning and final rotation logs. While the African mahogany plantations were predominately established for the production of sawlogs to pursue high-value sawn-timber markets, the large proportion of relatively short bole trees $(<3 \mathrm{~m})$ and a wide range of tree diameters (including a proportion of trees with diameters $<30 \mathrm{~cm}$ ) may restrict the efficiency of this processing approach.

Previous research has demonstrated the potential to use emerging spindleless rotary veneering technologies to process hardwood plantation and native forest logs of sizes and qualities previously considered un-merchantable (McGavin et al. 2014a, 2014b, 2015a,b; McGavin and Leggate 2019). This research has shown that spindleless rotary veneering can recover much higher proportions of marketable products from smaller diameter and lower quality logs than can be achieved through sawing. Rotary veneer processing, using spindleless lathe technology, may prove to be a more efficient processing method for African mahogany logs.

Limited information exists about the suitability and efficiency of both sawing and rotary peeling processing approaches for plantation-grown African mahogany. Similarly, there is limited understanding of the product quality and variation of qualities that are recovered from these processes. Furthermore, it is unclear how the variation between plantations and the plantation management approaches impacts the volume and quality of the products recovered. Without this understanding, making informed decisions regarding optimal plantation management regimes (e.g., silviculture) and identifying the most profitable markets that best suits the Australian plantation African mahogany resource will be challenging.

This study, using logs sourced from plantations that range in age, growing area, climate, and growth rate, compared the recovery rates and quality of wood product from traditional sawing approaches to that produced using spindleless veneer processing.

\section{EXPERIMENTAL}

\section{Materials}

\section{Plantation resource}

Four Australian African mahogany plantations were selected to enable sampling from a range of environmental conditions and silvicultural management regimes. Two sites were in the Douglas Daly Region, Northern Territory (Why Not and Kumbyechants); one north of Cooktown, Queensland (Elderslie); and one at Bowen, Queensland (Windermere). 
The Windermere plantation at Bowen was a smaller agroforestry planting in which the Queensland Government had established a thinning research trial in 2011. The other three plantations are industrial plantings.

The silvicultural history for each site is provided in Table 1. Trees were harvested between May and July 2017. Windermere plantation was the oldest at 19 years old, and Kumbyechants was the youngest at 7.5 years old. The Why Not and Elderslie plantations were similar ages at 11 and 13 years old, respectively. All plantations had been previously thinned and pruned.

Table 1. Plantation Silvicultural History

\begin{tabular}{|c|c|c|c|c|}
\hline & $\begin{array}{c}\text { Why Not, } \\
\text { Douglas Daly, } \\
\text { NT }\end{array}$ & $\begin{array}{c}\text { Kumbyechants, } \\
\text { Douglas Daly, } \\
\text { NT }\end{array}$ & $\begin{array}{l}\text { Windermere, } \\
\text { Bowen, } \\
\text { QLD }\end{array}$ & $\begin{array}{l}\text { Elderslie, } \\
\text { Cooktown, } \\
\text { QLD }\end{array}$ \\
\hline $\begin{array}{l}\text { Planting Date } \\
\text { (Age at time of } \\
\text { sampling) }\end{array}$ & $\begin{array}{l}\text { Early } 2006 \\
(11 \mathrm{yrs})\end{array}$ & $\begin{array}{c}\text { Jan } 2010 \\
(7.5 \text { yrs })\end{array}$ & $\begin{array}{l}\text { June } 1998 \\
\text { (19 yrs) }\end{array}$ & $\begin{array}{c}2004 \\
(13 \text { yrs })\end{array}$ \\
\hline $\begin{array}{c}\text { Planting Density } \\
\text { (sph) }\end{array}$ & 460 & 1170 & 666 & 470 \\
\hline $\begin{array}{c}\text { Non-commercial } \\
\text { Thinning (Age } \\
\text { and Density } \\
\text { (sph)) }\end{array}$ & $7 \mathrm{yr}$ to 280 & $3 \mathrm{yr}$ to 510 & $13 \mathrm{yr}$ to 250 & $7 \mathrm{yr}$ to 320 \\
\hline $\begin{array}{c}\text { Pruning (Age and } \\
\text { Target Pruning } \\
\text { Height) }\end{array}$ & $\begin{array}{l}5 \mathrm{yr} \text { to } 3.5 \mathrm{~m} \\
7 \mathrm{yr} \text { to } 4.5 \mathrm{~m}\end{array}$ & $4 \mathrm{yr}$ to $3.4 \mathrm{~m}$ & $\begin{array}{l}6 \mathrm{yr} \text { to } 3.5 \mathrm{~m} \\
8 \mathrm{yr} \text { to } 4.5 \mathrm{~m}\end{array}$ & $6 \mathrm{yr}$ to $4.5 \mathrm{~m}$ \\
\hline $\begin{array}{l}\text { Fertilizer (Number } \\
\text { of Applications, } \\
\text { Year, and Volume } \\
\text { of Application) }\end{array}$ & $\begin{array}{c}\text { 1x Application } \\
2010 \\
27 \mathrm{~kg} \mathrm{~N} / \mathrm{ha} \\
17 \mathrm{~kg} \mathrm{P} / \mathrm{ha} \\
25 \mathrm{~kg} \mathrm{~K} / \mathrm{ha} \\
\end{array}$ & $\begin{array}{l}\text { 4x Applications } \\
2010 \text { to } 2014 \\
\text { Total N } \sim 70 \mathrm{~kg} / \mathrm{ha} \\
\text { Total P } \sim 85 \mathrm{~kg} / \mathrm{ha}\end{array}$ & Nil & $\begin{array}{c}\text { 1x Application } \\
2007 \\
18 \mathrm{~kg} \mathrm{~N} / \mathrm{ha} \\
12 \mathrm{~kg} \mathrm{P} / \mathrm{ha} \\
15 \mathrm{~kg} \mathrm{~K} / \mathrm{ha} \\
\end{array}$ \\
\hline
\end{tabular}

Note: sph $=$ Stems per hectare, NCT = Non-commercial thinning, $\mathrm{N}=$ nitrogen, $\mathrm{P}=$ phosphorus, $\mathrm{K}=$ potassium, $\mathrm{kg} / \mathrm{ha}=$ kilograms per hectare, and $\mathrm{Nil}=$ no fertiliser application

Climate estimates from the SILO climate records system (Queensland Government 2020) were obtained for the period over which each plantation was grown from planting (Table 1) through to 2017 when the trees were harvested.

Table 2. Climatic Characteristics for the Four Sample Sites

\begin{tabular}{|c|c|c|c|c|}
\hline & Why Not & Kumbyechants & Windermere & Elderslie \\
\hline Mean Max Temp $\left({ }^{\circ} \mathrm{C}\right)$ & 34.2 & 34.3 & 28.6 & 28.9 \\
\hline Mean Min Temp $\left({ }^{\circ} \mathrm{C}\right)$ & 20.3 & 20.5 & 19.4 & 22.3 \\
\hline Annual Rainfall $(\mathrm{mm})$ & 1365 & 1434 & 826 & 1562 \\
\hline Annual Evaporation $(\mathrm{mm})$ & 2506 & 2497 & 2056 & 2032 \\
\hline $\begin{array}{c}\text { Climate Wetness Index } \\
\text { (Rainfall/Evaporation) }\end{array}$ & 0.54 & 0.57 & 0.41 & 0.76 \\
\hline Source: Queensland Government 2020 & \\
\hline
\end{tabular}

The climate varied between the four sites, with the Elderslie and Windermere sites being the wettest and driest, respectively. The rainfall and evaporation for the Douglas Daly sites (Why Not and Kumbyechants) were midway between the two Queensland sites (Table 2). The Douglas Daly sites had 5 to $6{ }^{\circ} \mathrm{C}$ higher maximum temperatures, and 
minimum temperatures were relatively similar (between 19.4 and $22.3^{\circ} \mathrm{C}$ ). Within the Douglas Daly region, the more northern Kumbyechants site had a higher rainfall than the southern Why Not site. However, this difference is estimated from the climate model to be relatively small and local knowledge indicates that the more southern site may have around $200 \mathrm{~mm}$ less annual rainfall.

Trees of superior quality (i.e., high growth rate and form) were targeted that represent the upper $10 \%$ of tree size and log quality (as judged by straightness, lack of deformities, branching defects, etc.). This selection protocol was followed for Why Not, Kumbyechants, and the Elderslie plantation. However, due to the need to maintain the integrity of the thinning trial at Windermere, only average-sized trees (rather than superior trees) were available for sampling.

\section{Tree Harvesting, Log Merchandising, and Allocation}

The selected trees were merchandised immediately after harvesting to provide a target butt log length of approximately $3 \mathrm{~m}$. Logs were end-sealed after merchandising and transported to Queensland Department of Agriculture and Fisheries (DAF), Salisbury Research Facility in Brisbane, Queensland. The time between harvesting and delivery to the Salisbury Research Facility was minimized to limit log degradation.

The allocation of logs within each plantation batch to processing method (either peeling or sawing) was made by ranking each log by small-end diameter and then systematically allocating each log to a processing method with two logs allocated to sawing for each log allocated to peeling.

Logs allocated to veneer processing (peeling) were further merchandised to provide two $1.5 \mathrm{~m}$ peeler billets per log. Logs allocated to sawmilling were not merchandised further unless severe defects were identified. This resulted in similar log/billet numbers for each processing method. The following parameters were measured on each sawlog and peeler billet:

- Large-end diameter under bark or $\operatorname{LEDUB}(\mathrm{m})$ - measured from the circumference with a diameter tape;

- Small-end diameter under bark or $\operatorname{SEDUB}(\mathrm{m})$ - measured from the circumference with a diameter tape;

- Log length or $L(\mathrm{~m})$ - measured using a length tape;

- Log sweep deviation or $a(\mathrm{~mm})$ - measured as the maximum distance on the curved side of a log when a line is extended between the log ends and specifically used to calculate log sweep (see Eq. 2 below);

- Shortest small-end diameter or $S D(\mathrm{~m})$ - the shortest small-end diameter measured using a steel rule;

- Longest small-end diameter or $L D(\mathrm{~m})$ - the longest small-end diameter measured using a steel rule.

From the measured data, individual green log volume, $V\left(\mathrm{~m}^{3}\right)$; $\log$ sweep, $S(\mathrm{~mm} / \mathrm{m}) ; \log$ ovality, $O(\%)$; and $\log$ taper, $T(\mathrm{~mm} / \mathrm{m})$ were determined using Eqs. 1 to 4, respectively,

$$
\begin{aligned}
& V=\left(\frac{S E D U B+L E D U B}{2}\right)^{2} \times \pi \times L \\
& S=\frac{a}{L} \\
& O=\frac{L D-S D}{L D} \times 100
\end{aligned}
$$




$$
T=\frac{L E D U B-S E D U B}{L}
$$

where $\pi$ is the mathematical constant number pi and all other variables are previously defined.

\section{Rotary Veneer Processing}

\section{Log conversion}

Peeler billets were processed using a semi-industrial-scale spindleless veneer lathe (Model SL1350/5, BSY Industry Group, Weihai, China). The lathe is capable of processing billets up to $1300 \mathrm{~mm}$ in length and $500 \mathrm{~mm}$ in diameter. The minimum peeler core size is $40 \mathrm{~mm}$. For the study, a nominal dried veneer thickness of $2.5 \mathrm{~mm}$ was selected. The peeler billets were pre-heated prior to peeling using saturated steam until the billet cores reached approximately $65^{\circ} \mathrm{C}$. Immediately after being pre-heated, billets were docked to $1300 \mathrm{~mm}$ billet lengths, debarked, and rounded in a dedicated rounding lathe before being peeled into veneer. All logs were processed in a similar manner.

\section{Veneer management}

The resulting veneer ribbon was sequentially clipped to sheets with a $1350 \mathrm{~mm}$ maximum width. Veneer sheets were labelled with a unique identifier and seasoned with a commercial veneer jet-box drier at a nominal $165{ }^{\circ} \mathrm{C}$ to a target moisture content of $8 \%$. The following parameters were measured on the veneer sheets:

- Dried veneer thickness (DT) - the mean thickness of each dried veneer sheet, measured using a dial thickness gauge at four locations along the sheet length;

- Dried veneer width $(D W)$ - the width (perpendicular to grain) of each dried veneer sheet.

\section{Veneer grading}

The Australian veneer industry has adopted Australian and New Zealand standard AS/NZS 2269.0 (2012) to visually segregate the grade quality of veneer. The standard separates structural veneer, according to severity and concentration of imperfections and defects, into four veneer surface qualities (A -highest quality, B, C, and D-grade) and a reject grade.

The AS/NZS 2269.0 (2012) standard does not include a specific provision for grading veneer for compression or flatness. The acceptance of this defect is determined during the manufacturing process (i.e., industry understanding of the severity of compression and waviness that can be managed through the process without causing problems with drying, bonding, and product pressing), and the effects of the defect (e.g., splits, poor bonds, panel product flatness, etc.) are managed in the final product grading rather than at the veneer stage.

As part of the veneer assessment process, two experienced veneer industry experts were invited to assist in the development of a criteria to quantify the presence and severity of compression in the recovered veneers. The recovered veneer sheets were graded in line with quality expectations of the A to D-grade criteria. However, no veneer sheets were rejected due to compression. Instead, all veneers assigned D-grade for compression were further segregated into a 1 to 4 category (with D1 being better than D4). 


\section{Veneer recovery}

Four recovery calculation methods like that described by McGavin et al. (2014a) were used: dry veneer recovery, gross veneer recovery, net veneer recovery, and graded veneer recovery.

Dry veneer recovery provides a useful measure of the maximum recovery, taking into account log geometry (e.g., sweep, taper, circularity), lathe limitations (e.g., peeler core size), and the drying process (e.g., veneer shrinkage, etc.). Dry veneer recovery disregards internal log quality. Dry veneer recovery $(D R$ as a \%) was calculated according to Eq. 5,

$$
D R=\frac{L \times \sum_{\text {veneer }}(D T \times D W)}{\sum_{\text {billet }} V} \times 100
$$

where $D T$ is the average dry veneer thickness of each veneer $(\mathrm{m}), D W$ is the dry veneer width ( $\mathrm{m}$, perpendicular-to-grain), and all other variables are previously described.

Gross veneer recovery provides a valuable assessment of the maximum recovery of dried veneer that satisfies the quality specifications of AS/NZS 2269.0 (2012). This recovery measure takes into account the losses acknowledged in dry veneer recovery but also considers the additional losses from visual grading where a proportion of the veneer can fail to meet grade. Gross veneer recovery ( $G S R$ as \%) was calculated according to Eq. 6 ,

$$
G S R=\frac{L \times \sum_{\text {veneer }}(D T \times G R W)}{\sum_{\text {billet }} V} \times 100
$$

where $G R W$ is the width (m, perpendicular to the grain) of dried veneer that meets the A, B, C, and D grade requirements in accordance with AS/NZS 2269.0 (2012) and all other variables are previously described.

Net veneer recovery is an effective measurement of process efficiency, as it isolates the saleable product, while considering the product manufacturing restrictions. Net veneer recovery includes the losses accounted for in gross veneer recovery and also the additional reduced volume due to the trimming of veneer before, during, and after product manufacture. McGavin et al. (2014a) described the loss incurred when veneer sheets are reduced in width to the final product size as a trimming factor. In this study, the trimming factor was 0.94. This corresponds to reducing the veneer sheet width perpendicular to the grain from $1275 \mathrm{~mm}$ (nominal width post seasoning) to $1200 \mathrm{~mm}$. The veneer sheet parallel to the grain was systematically reduced from $1300 \mathrm{~mm}$ to $1200 \mathrm{~mm}$. Net veneer recovery (NR as \%) was calculated according to Eqs. 5 and 6:

$$
\begin{aligned}
& N R=G S R \times 0.94 \times \frac{1200}{1300} \\
& N R=G S R \times 0.869
\end{aligned}
$$

Graded veneer recovery is the net veneer recovery for each grade as defined by AS/NZS 2269.0 (2012) (i.e., A, B, C, or D grades). Graded veneer recovery was calculated for each grade quality and is defined as $N R_{\mathrm{A}}, N R_{\mathrm{B}}, N R_{\mathrm{C}}$, and $N R_{\mathrm{D}}$.

\section{Sawmill Processing}

\section{Log conversion}

The logs allocated to sawmilling were processed using a Kara-Master processing system (Kallion Konepaja Oy, Raisio, Finland). The sawmill was equipped with a 1016 $\mathrm{mm}$ diameter circular saw that resulted in a $6 \mathrm{~mm}$ kerf width. While this equipment design 
features a single circular saw, the sawing approach adopted for the study mirrored common commercial twin-edge processing strategies used in many modern hardwood sawmills and targeted predominately two different nominal board dimensions: $100 \mathrm{~mm}$ x $25 \mathrm{~mm}$; and $150 \mathrm{~mm} \times 25 \mathrm{~mm}$. These board dimensions are commonly targeted by the Australian hardwood sector due to their suitability for flooring and joinery type products. Two smaller nominal board dimensions of $100 \mathrm{~mm}$ x $20 \mathrm{~mm}$ and $150 \mathrm{~mm}$ x $20 \mathrm{~mm}$, were also recovered to further maximize recovery with these nominal dimensions being suitable for products such as internal wall panelling. Boards were sawn at a dimension slightly greater than the nominal dimension to allow for shrinkage during drying.

Recovered boards were labelled with a unique identifier before having any obvious want and wane removed from the board ends. Board dimensions (nominal width, thickness, and board length) were recorded. Boards were then seasoned using conventional, techniques that included a short period of air-drying, followed by mild kiln drying to a target moisture content of $10 \%$.

\section{Sawn timber grading}

Dried boards were graded according to Australian standard AS 2796.2 (2006). This standard is well accepted by the Australian hardwood timber industry, which segregates sawn and milled products into three grade qualities: Select Grade (highest quality), Medium Feature Grade, and High Feature Grade (lowest quality). Each board was visually graded to all three grades individually to determine the grade recovery of each specific grade. The most influential defect type that caused boards to be downgraded/rejected was recorded. Note that other grade limiting defects may have been present; however, only the most obvious defects were recorded. A minimum piece length was set at $900 \mathrm{~mm}$.

At the time of grading, board distortion characteristics (i.e., twist, spring, and bow) were measured on the boards at their entire length. Reducing board lengths by docking as part of a commercial grading process would be expected to reduce the severity of board distortion present in the final 'graded' board dimension. As the boards were only 'hypothetically' docked during the grading process, board distortion limits were not included in the grade recovery analysis, they were analysed separately.

\section{Sawn timber recovery}

Three recovery calculation methods were used: sawn recovery $(S R) \%$; sawngraded recovery $(S G R)$; and dried-dressed recovery $(D D R)$. Sawn recovery, $S R(\%)$, provides a useful measure of the percentage of log volume converted into boards from the sawing process (mainly influenced by log size and geometry, and processing equipment). The sawn recovery was calculated for each log according to Eq. 8,

$$
S R=\frac{\sum_{\text {board }}(W \times T \times L)}{\sum_{\log V} V} \times 100
$$

where $W$ is the sawn board nominal dried width $(\mathrm{m}), T$ is the sawn board nominal dried thickness $(\mathrm{m}), L$ is the sawn board length $(\mathrm{m})$, and all other variables are previously described.

Sawn graded recovery, SGR (\%), includes the losses accounted for in sawn recovery but includes the losses that occur through the grading process (e.g., due to presence of internal $\log$ imperfections and defects). The sawn graded recovery was calculated according to Eq. 9, 


$$
S G R=\frac{\sum_{\text {board }}(W \times T \times G L)}{\sum \log V} \times 100
$$

where $G L$ is the sawn board length (m) that met the grade requirements of AS 2796.2 (2006) and all other variables are previously described.

Dried-dressed recovery, $D D R(\%)$, includes the losses accounted for in sawn and sawn graded recoveries but additionally includes the losses due to dressing (or machining) to a final dimension, e.g., the tongue and groove flooring. The dried-dressed recovery was calculated according to Eq. 10,

$$
D D R=\frac{\sum_{\text {board }}(D D W \times D D T \times G L)}{\sum_{\log V} V} \times 100
$$

where $D D W$ is the board nominal width (m) after drying and dressing (or profiling), $D D T$ is the board nominal thickness (m) after drying and dressing (or profiling), and all other variables are previously described.

\section{Statistical Analysis}

Statistical analysis was conducted using Microsoft Excel (Microsoft Office Professional Plus 2016, Microsoft Corporation, Redmond, WA, USA) and Minitab 19 Statistical Software (Minitab, Inc., State College, PA, USA). Box plots have been used to display several sets of data with the following format:

- $\quad$ the lower edge of the box represents the first quartile Q1,

- a black horizontal line within the box represents the median Q2 ,

- a red cross represents the average,

- $\quad$ the upper edge of the box represents the third quartile Q3.

Two intervals are defined on either side of the first and third quartiles:

$\mathrm{IQ} 1=[\mathrm{Q} 1-1.5 \times(\mathrm{Q} 3-\mathrm{Q} 1), \mathrm{Q} 1]$

$\mathrm{IQ} 3=[\mathrm{Q} 3, \mathrm{Q} 3+1.5 \times(\mathrm{Q} 3-\mathrm{Q} 1)]$

- $\quad$ The lower part of the box plot reaches from Q1 to the value nearest to the lower bound of IQ1, while remaining within IQ1,

- $\quad$ The upper part of the box plot reaches from Q3 to the value nearest to the upper bound of IQ3, while remaining within IQ3,

- The values underneath the lower part and above the upper part are represented individually by circles. These circles are filled when the values are more than 3 times the distance between the quartiles $(\mathrm{Q} 3-\mathrm{Q} 1)$, and are empty if they are within that interval.

\section{RESULTS AND DISCUSSION}

\section{Resource}

Thirty-nine trees were harvested for the study from the four plantations. Table 3 provides comparative details of the mean tree diameter (at breast height over bark, DBHOB) of the plantations at the time of tree selection and the mean diameter of selected trees harvested for the study. The higher mean DBHOB of sampled trees compared with the wider plantation trees for Why Not, Kumbyechants, and Elderslie plantations confirmed the strategy of selecting superior quality trees for the study. As previously noted, only average-sized trees were selected from the Windermere plantation. 
Table 3. Sampled Tree Characteristics Relative to Surrounding Trees

\begin{tabular}{|c|c|c|c|c|}
\hline & Why Not & Kumbyechants & Windermere & Elderslie \\
\hline $\begin{array}{c}\text { Mean DBHOB of } \\
\text { Plantation Trees (mm) }\end{array}$ & 228 & 176 & 257 & 250 \\
\hline $\begin{array}{c}\text { Mean DBHOB of } \\
\text { Sampled Trees (mm) }\end{array}$ & 268 & 255 & 253 & 356 \\
\hline $\begin{array}{c}\text { Number of Tree } \\
\text { Samples }\end{array}$ & 9 & 9 & 12 & 9 \\
\hline
\end{tabular}

From the harvested trees, $56 \operatorname{logs}\left(6.376 \mathrm{~m}^{3}\right)$ resulted after final merchandising with $32 \operatorname{logs}\left(1.918 \mathrm{~m}^{3}\right)$ being allocated to rotary veneer processing and $24 \operatorname{logs}\left(4.458 \mathrm{~m}^{3}\right)$ allocated to sawmilling (Table 4). The method of log allocation ensured that there was minimal variation in $\log$ SEDUB between the two processing methods (sawing and rotary peeling). The variation in average log volume between the two processing methods is explained by the shorter log length used for rotary peeling ( $1.3 \mathrm{~m}$ versus approximately 3.0 $\mathrm{m}$ used for sawing).

The logs sourced from Elderslie were the largest in diameter and the Windermere logs were the smallest (Table 4). This is despite the Windermere trees being 6 years older than the Elderslie trees (19 years old versus 13 years old). Even though the selected Why Not trees were of similar age to the Elderslie trees, the Why Not logs were smaller and similar in size to the Kumbyechants selected logs, despite the latter being approximately 3.5 years younger ( 7.5 years old).

Table 4. Log Characteristics

\begin{tabular}{|c|c|c|c|c|c|c|}
\hline & $\begin{array}{c}\text { Processing } \\
\text { Method }\end{array}$ & $\begin{array}{c}\text { Number } \\
\text { of Logs }\end{array}$ & $\begin{array}{c}\text { Average } \\
\text { Log } \\
\text { Length } \\
\mathbf{( m )}\end{array}$ & $\begin{array}{c}\text { Average Log } \\
\text { Small-end } \\
\text { Diameter } \\
\text { Under Bark } \\
(\mathbf{m m})^{*}\end{array}$ & $\begin{array}{c}\text { Average } \\
\text { Log } \\
\text { Volume } \\
\left(\mathbf{m}^{3}\right)\end{array}$ & $\begin{array}{c}\text { Total Log } \\
\text { Volume } \\
\text { Processed } \\
\left.\mathbf{( m}^{3}\right)\end{array}$ \\
\hline \multirow{3}{*}{ Why Not } & Sawing & 6 & 3.1 & $\begin{array}{c}216 \\
(13.7)\end{array}$ & 0.149 & 0.896 \\
\cline { 2 - 7 } & Peeling & $7^{* *}$ & 1.3 & $\begin{array}{c}219 \\
(17.2)\end{array}$ & 0.055 & 0.386 \\
\hline \multirow{3}{*}{ Kumbyechants } & Sawing & 6 & 2.9 & $\begin{array}{c}220 \\
(22.9)\end{array}$ & 0.149 & 0.895 \\
\cline { 2 - 7 } & Peeling & $7^{* *}$ & 1.3 & $\begin{array}{c}200 \\
(24.2)\end{array}$ & 0.049 & 0.344 \\
\hline \multirow{3}{*}{ Elderslie } & Sawing & 6 & 3.0 & $\begin{array}{c}187 \\
(19.6)\end{array}$ & 0.130 & 0.778 \\
\cline { 2 - 7 } & Peeling & 12 & 1.3 & $\begin{array}{c}197 \\
(18.5)\end{array}$ & 0.049 & 0.585 \\
\cline { 2 - 7 } & Sawing & 6 & 3.1 & $\begin{array}{c}307 \\
(52.0)\end{array}$ & 0.315 & 1.889 \\
\hline \multirow{2}{*}{ Peeling } & 6 & 1.3 & $\begin{array}{c}291 \\
(33.5)\end{array}$ & 0.101 & 0.603 \\
\hline
\end{tabular}

${ }^{*}$ : Standard deviation presented in parentheses; ${ }^{* *}$ : One log yielded 3 peeler billets after final merchandising, while the balance yielded 2 peeler billets

The variation in selected log diameter between sites would be influenced by various factors resulting in tree growth rate differences between the sites. However, the variation in tree selection strategy between Windermere and the other sites meant that the overall 
plantation growth data provided a better assessment of the growth between the sites rather than the diameter of the selected log sizes, which was influenced by the sampling strategy. For example, while the logs sourced from Elderslie were the largest in diameter and the Windermere logs were the smallest, the mean tree DBHOB at the Windermere plantation was slightly larger than Elderslie $(257 \mathrm{~mm}$ and $250 \mathrm{~mm}$, respectively). Much of the variation in size of logs from Windermere compared to the other sites can be explained by the average size trees selected from this site for the study, compared to the superior trees selected from the other sites.

Figures 1 through 3 illustrate the variation in log taper, log sweep, and log small end ovality for the selected logs from each site. The results highlight the relatively large taper that exists in these logs regardless of site and growing condition. The taper was well over triple of what would be expected from other plantation hardwood species (e.g., Eucalyptus and Corymbia spp.) (McGavin et al. 2014a). There was little variation in the mean log taper between the sites (range 31 to $37 \mathrm{~mm} / \mathrm{m}$ ) and the median values for taper varied from 29 to $33 \mathrm{~mm} / \mathrm{m}$. The variation in taper within each site was much higher than the variation between the sites (Fig. 1). Log taper negatively affects recovering through both sawing and veneer processing (Walker 2006; Venn et al. 2020).

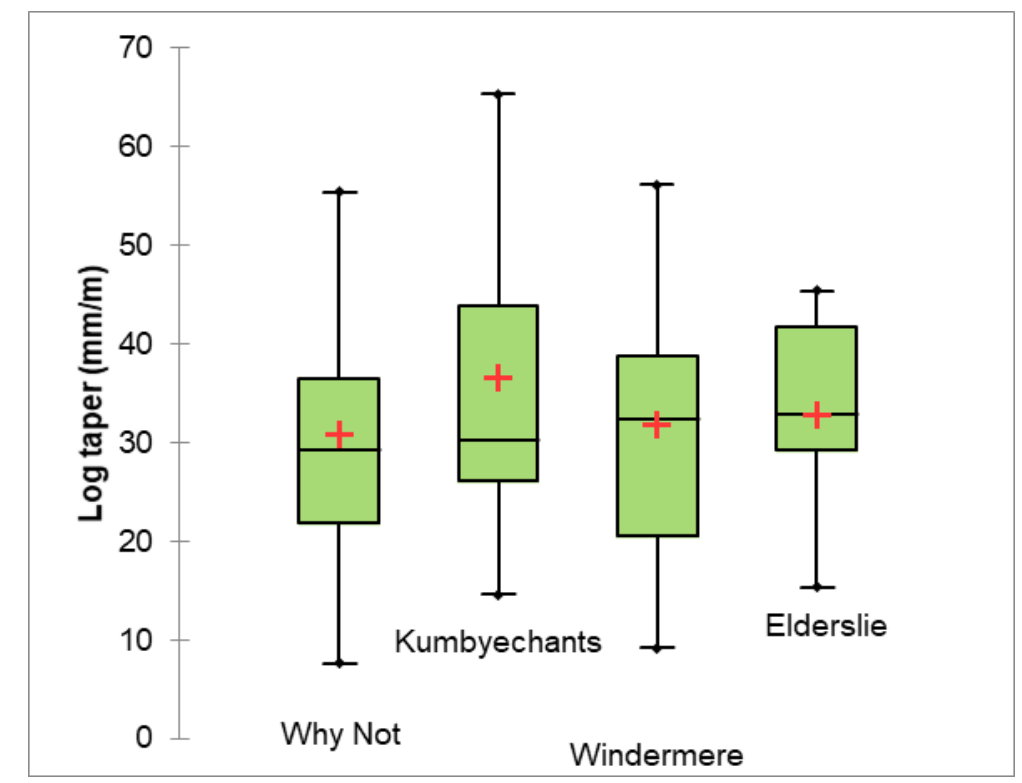

Fig. 1. Log taper (Why Not $n=13$, Kumbyechants $n=13$, Windermere $n=18$, and Elderslie $n=12$ )

Similarly, the log sweep was high, especially given the log selection criteria that provided predominately superior quality trees based on log size and form. The variation within the sites was high and particularly for the trees from Windermere. This may reflect the different selection protocol for this site, within which the average, rather than superior trees, was sampled due to constraints with the thinning trial from which this material was sourced.

Log ovality was shown by Venn et al. (2020) to have less impact on veneer recovery compared with sweep and taper; however, it did have an undesirable influence. The impact of ovality is probably greater for veneer processing compared to sawmilling, as essentially no useable veneer can be recovered from the log until it is rounded to a cylinder with consistent diameter and parallel sides (e.g., ovality removed). Sawmilling is potentially 
more flexible in recovering product from logs that are oval shaped. The presence of log ovality in the four sampled plantations showed wide within-site variation and similar mean ovality values between $5 \%$ and $7 \%$ (Fig. 3).

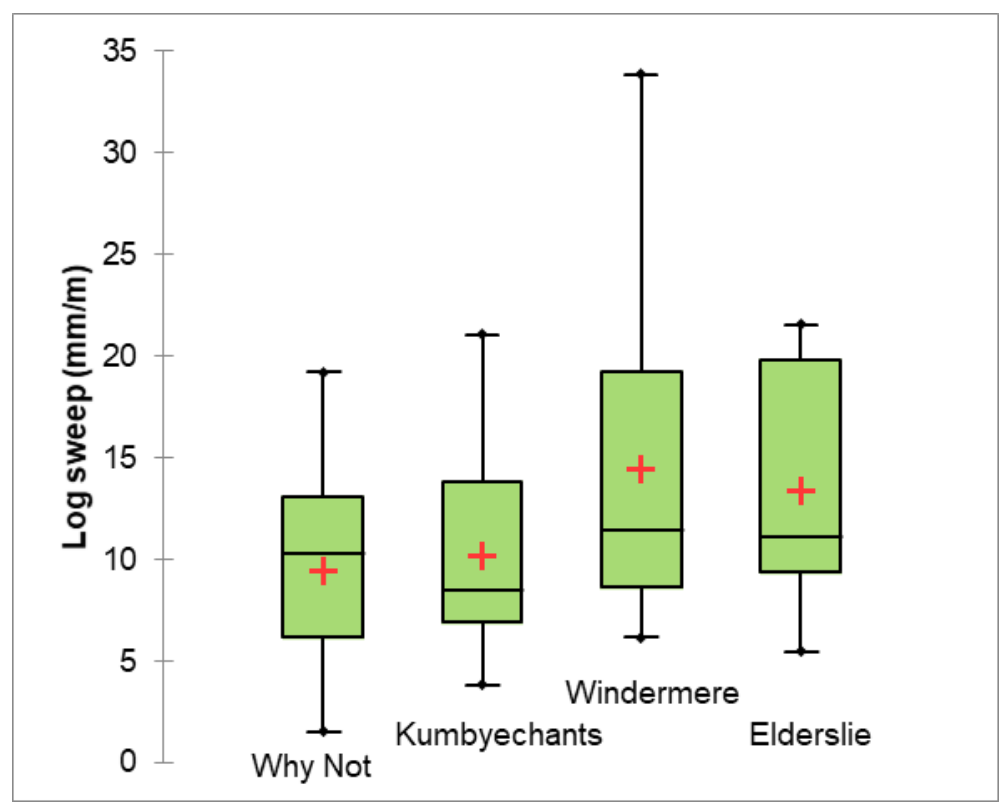

Fig. 2. Log sweep (Why Not $n=13$, Kumbyechants $n=13$, Windermere $n=18$, and Elderslie $n=12$ )

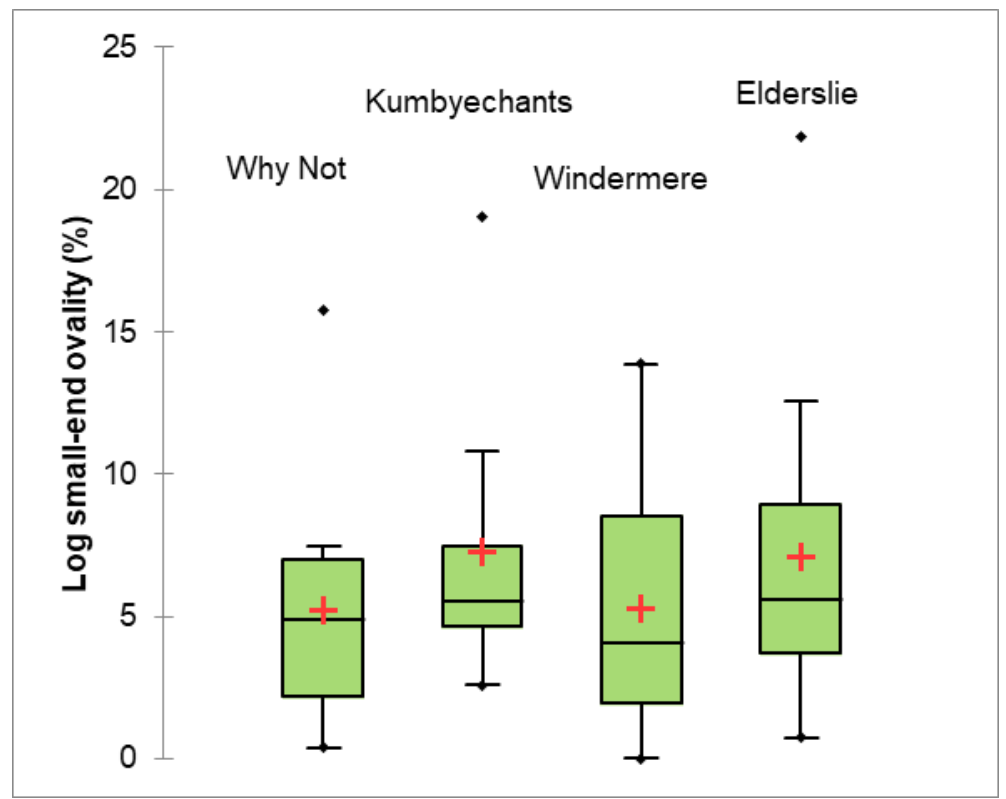

Fig. 3. Log small end ovality (Why Not $n=13$, Kumbyechants $n=13$, Windermere $n=18$, and Elderslie $n=12$ )

\section{Rotary Veneer Processing}

Figure 4 shows the recovery of dry veneer from each of the plantations. The calculation method for dry veneer recovery does not include grading for defects (internal billet features). Most of the variation in recovery between plantations can be explained by 
the log geometry (diameter and form deviation from a cylindrical column) rather than other factors such as tree age, wood quality, or impacts of silviculture (Venn et al. 2020).

The Why Not billets yielded the highest dry veneer recovery with a mean value of $73 \%$, followed by the Kumbyechants and Elderslie billets with $68 \%$, while the Windermere billets produced the lowest dry veneer recovery (56\%) (Fig. 4 and Table 5). This was despite the Elderslie billets having the highest mean small-end diameter. The higher dry veneer recovery from the Why Not billets can be explained by the influence of the lowest average log taper, lowest average log sweep, and lowest average log ovality meaning that less of the billet volume was lost during the billet rounding phase, where no veneer can be recovered. The low veneer recovery at Windermere was influenced by the smaller log diameters and the high level of log sweep. Although the log taper and ovality results for the Windermere billets were comparable to the other sites, the negative impact of these features is further compounded by the smaller billet diameters (e.g., the ratio of sweep to diameter is greater).

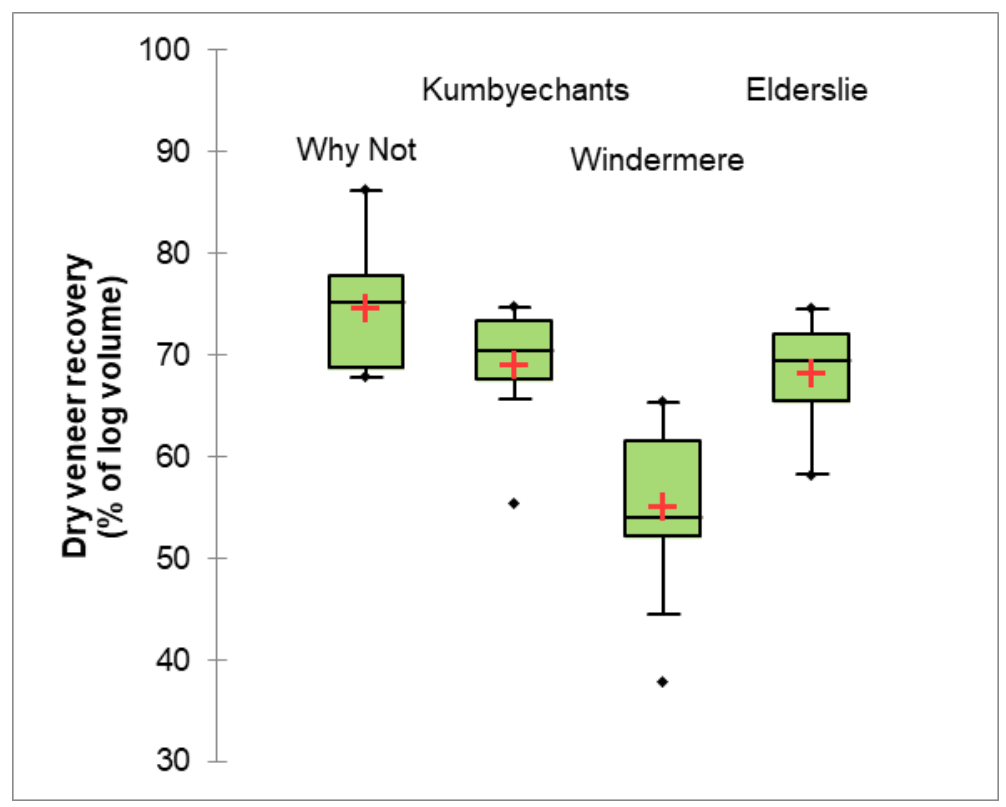

Fig. 4. Dry veneer recovery (Why Not $n=13$, Kumbyechants $n=13$, Windermere $n=18$, and Elderslie $n=12$ )

The Elderslie billets yielded the highest gross veneer recovery (63\%), with Why Not billets ranking third (behind Kumbyechants) (Table 5). This change of order compared to the dry veneer recovery results indicates that the internal log defects in the Elderslie billets had less of an impact on limiting veneer grades compared to the Why Not billets.

To separate the internal billet imperfections from the billet geometry, the gross recovery presented as the percentage of dry veneer volume (rather than log volume) provided a useful comparison (Table 5). The Elderslie billets yielded the highest gross veneer recovery (93\% of dry veneer volume), confirming a lower proportion of the recovered veneers were negatively affected by internal billet defects. This result is likely to have been aided by the larger diameter of the Elderslie billets (e.g., more volume of wood post pruning where defects are expected to be less frequent). The Windermere veneer ranked second with $87 \%$ recovery. Why Not veneer ranked lowest with $71 \%$ recovery, essentially losing the benefits gained at the dry veneer recovery stage. This indicated that 
the recovered veneer from this site contained higher levels of defects and imperfections that negatively affected the grade quality compared to the other sites.

The net recovery presents the percentage of the billet volume that is marketable (veneer that is dried, graded, and trimmed to a nominal final product dimension). The Elderslie billets achieved the highest net recovery at 55\% of log volume, attributed to the larger billet diameter and less internal imperfections. Kumbyechants billets ranked second (50\%), followed by Why Not billets $(45 \%)$. The Windermere billets had the lowest net recovery $(42 \%)$, demonstrating that although the internal billet imperfections were comparatively low, it could not offset the negative impacts that resulted from the billet geometry.

The recovery values achieved are similar to the rotary veneer recovery analysis reported by McGavin et al. (2014a) for six different hardwood plantation species (Eucalyptus and Corymbia species) and McGavin and Leggate (2019) when rotary peeling small-diameter native forest logs using similar processing methods.

Table 5. Veneer Recoveries

\begin{tabular}{|c|c|c|c|c|}
\hline & $\begin{array}{c}\text { Dry Veneer } \\
\text { Recovery } \\
\text { (\% of Log } \\
\text { Volume) }\end{array}$ & $\begin{array}{c}\text { Gross Veneer } \\
\text { Recovery } \\
\text { (\% of Log } \\
\text { Volume) }\end{array}$ & $\begin{array}{c}\text { Gross Veneer } \\
\text { Recovery } \\
\text { (\% of Dry } \\
\text { Veneer } \\
\text { Volume) }\end{array}$ & $\begin{array}{c}\text { Net Veneer } \\
\text { Recovery } \\
\text { (\% of Log } \\
\text { Volume) }\end{array}$ \\
\hline Kumy Not & 73 & 52 & 71 & 45 \\
\hline Windermere & 56 & 57 & 84 & 50 \\
\hline Elderslie & 68 & 48 & 87 & 42 \\
\hline
\end{tabular}

The grade recovery analysis showed that most recovered veneers failed to make a grade higher than D-grade, the lowest grade quality in accordance with AS/NZS 2269.0 (2012) (Table 6).

Table 6. Graded Veneer Recoveries

\begin{tabular}{|c|c|c|c|c|c|c|c|}
\hline & $\begin{array}{c}\text { A- } \\
\text { grade } \\
\text { Recove } \\
\text { ry } \\
\text { (\% of } \\
\text { Log } \\
\text { Volume } \\
\text { ) }\end{array}$ & $\begin{array}{c}\text { B-grade } \\
\text { Recover } \\
y \\
\text { (\% of } \\
\text { Log } \\
\text { Volume) }\end{array}$ & $\begin{array}{c}\text { C-grade } \\
\text { Recover } \\
y \\
\text { (\% of } \\
\text { Log } \\
\text { Volume) }\end{array}$ & $\begin{array}{c}\text { D-grade } \\
\text { Recover } \\
\text { y (\% of } \\
\text { Log } \\
\text { Volume) }\end{array}$ & $\begin{array}{c}\text { B-grade } \\
\text { Recover } \\
y \\
\text { (\% of } \\
\text { Net } \\
\text { Veneer } \\
\text { Volume) }\end{array}$ & $\begin{array}{c}\text { C-grade } \\
\text { Recover } \\
y \\
\text { (\% of } \\
\text { Net } \\
\text { Veneer } \\
\text { Volume) }\end{array}$ & $\begin{array}{c}\text { D-grade } \\
\text { Recover } \\
\text { y (\% of } \\
\text { Net } \\
\text { Veneer } \\
\text { Volume) }\end{array}$ \\
\hline Why Not & 0 & 1 & 6 & 38 & 2 & 13 & 85 \\
\hline Kumbyechants & 0 & 3 & 7 & 40 & 6 & 14 & 80 \\
\hline Windermere & 0 & 6 & 10 & 26 & 13 & 24 & 63 \\
\hline Elderslie & 0 & 3 & 3 & 49 & 5 & 6 & 89 \\
\hline
\end{tabular}

No veneers met the requirements of A-grade. While D-grade is the lowest visual grade quality for structural veneer, the veneers are suitable for face veneers on nonappearance structural panels as well as the core veneers for most appearance and non- 
appearance structural panels. The low recovery of higher grade veneers $(\mathrm{C}$-grade and better), which are more suitable for face veneers, would make the commercial production of a standard mix of appearance veneer-based products challenging when only using a resource of this quality. The Windermere billets achieved the highest proportion of veneers that were graded as $\mathrm{C}$-grade or higher (24\% C-grade and $13 \% \mathrm{~B}$-grade). While the dry, gross, and net recoveries for this site were the lowest, with the potential to achieve higher grade qualities could be critically important to secure profitable markets. This outcome was likely influenced by these logs being much older.

Table 7 details the top 5 ranked defects that prevented veneer sheets from achieving a grade higher than D-grade. Note that some veneers may be grade limited due to more than one defect. As expected, there are similarities across all sites. Internal log natural defects, such as knots etc., were not the main influence in reducing grade, rather veneer defects that resulted from the interaction between the material and the conversion process featured most.

Table 7. Top 5 Ranked Defects Preventing Graded Veneers from Attaining Assigned Grades Higher than D-grade

\begin{tabular}{|c|c|c|c|c|c|}
\hline \multirow{2}{*}{ Why Not } & \multicolumn{5}{|c|}{ Rank } \\
\cline { 2 - 6 } & $\begin{array}{c}\text { Roughness } \\
(53 \%)\end{array}$ & $\begin{array}{c}\text { Compression } \\
(38 \%)\end{array}$ & $\begin{array}{c}\text { Grain } \\
\text { breakout } \\
(32 \%)\end{array}$ & $\begin{array}{c}\text { Splits } \\
(31 \%)\end{array}$ & $\begin{array}{c}\text { Cumulative } \\
\text { defects } \\
(20 \%)\end{array}$ \\
\hline Kumbyechants & $\begin{array}{c}\text { Compression } \\
(55 \%)\end{array}$ & $\begin{array}{c}\text { Grain } \\
\text { breakout } \\
(33 \%)\end{array}$ & $\begin{array}{c}\text { Roughness } \\
(31 \%)\end{array}$ & $\begin{array}{c}\text { Cumulative } \\
\text { defects } \\
(20 \%)\end{array}$ & $\begin{array}{c}\text { Wane } \\
(10 \%)\end{array}$ \\
\hline Windermere & $\begin{array}{c}\text { Roughness } \\
(33 \%)\end{array}$ & $\begin{array}{c}\text { Unsound } \\
\text { knots }- \\
\text { fractured } \\
(23 \%)\end{array}$ & $\begin{array}{c}\text { Unsound } \\
\text { knots-bark } \\
\text { encased } \\
(22 \%)\end{array}$ & $\begin{array}{c}\text { Compression } \\
(21 \%)\end{array}$ & $\begin{array}{c}\text { Wane } \\
(17 \%)\end{array}$ \\
\hline Elderslie & $\begin{array}{c}\text { Roughness } \\
(77 \%)\end{array}$ & $\begin{array}{c}\text { Compression } \\
(47 \%)\end{array}$ & $\begin{array}{c}\text { Grain } \\
\text { breakout } \\
(34 \%)\end{array}$ & $\begin{array}{c}\text { Unsound } \\
\text { knots- } \\
\text { fractured } \\
(22 \%)\end{array}$ & $\begin{array}{c}\text { Cumulative } \\
\text { defects } \\
(18 \%)\end{array}$ \\
\hline
\end{tabular}

Veneer surface roughness was the highest ranked defect for three sites and ranked third for the fourth site. Many factors can influence the severity of veneer surface roughness including resource orientated factors, such as grain angle, log taper, growth stresses, reaction wood, etc., as well as process orientated factors such as lathe setup, billet pretreatment method, temperature, target veneer thickness, knife sharpness, etc. Given the range of factors that potentially influence this defect, there may be opportunities to improve the veneer roughness through intervention, especially through process modification. Grain breakout was featured in three of the four sites. Grain breakout is like roughness in appearance, although it is often more concentrated in small zones and the resulting undulations can be much deeper. The causes for grain breakout are similar to veneer roughness.

Knot defects featured within the top five defects limited veneers from Windermere and Elderslie plantations to D-grade. The Windermere veneers were most affected with $23 \%$ and $22 \%$ of veneers being limited to D-grade due to unsound fractured knots and unsound bark-encased knots, respectively. With all sampled plantations receiving similar 
pruning treatments, it is unclear why Windermere in particular was most affected by knot defects, especially given this plantation was harvested at an older age by comparison to the other sites, which should have resulted in greater proportion of post-pruning veneer. Further investigation into the pruning methodology adopted at Windermere may assist in understanding the lower effectiveness that the pruning treatments had in producing knot and knot associated defect free wood.

The presence of wane was ranked fifth for the Kumbyechants and Windermere veneers. Wane is the natural absence of wood in the product section. This defect can be prevented by undertaking additional rounding-up prior to peeling. However, it is generally preferred to manage a small percentage of the natural log edge on the billet during peeling rather than risk the loss of log volume during round-up that may have produced usable veneer. Billets with smaller diameters and non-uniform shapes (taper, sweep, ovality, and fluting) can increase the occurrence of wane in recovered veneer sheets.

Cumulative defects are described as an area within the veneer sheet that contains more than one defect in close proximity to others, which if assessed individually would not limit the veneer grade, but when measured cumulatively in accordance with AS/NZS 2269.0 (2012), either limits grade potential or results in the veneer sheet being rejected. This defect category prevented approximately $20 \%$ of the veneers from Why Not, Kumbyechants, and Elderslie and $9 \%$ of Windermere veneers achieved a grade higher than D-grade. Indeed, cumulative defects were the main cause of veneers from all sites failing to achieve D-grade (i.e., reject grade).

A high presence of compression was observed in the recovered veneer sheets, and this was supported by this defect ranking in the top 4 defects preventing veneers from achieving grades higher than D-grade across all sites. Veneer compression is evidenced by the lack of sheet flatness and a wavy undulating surface. Veneer sheets containing a high level of compression and waviness can be difficult to dry (e.g., can jam drier systems) and are difficult to store in stable packs. Affected veneer may be unable to be passed through conventional adhesive application equipment, or if they are able to be passed through, the adhesive is spread in an uneven manner leading to poor bonding in the manufactured product. Veneers containing compression tend to split when the sheets are forced flat during pressing for product manufacture resulting in downgraded and a poor quality product.

Figure 5 illustrates the distribution of veneer compression grading for the four sites. While the market acceptance of compression affected mahogany veneer is untested, it was estimated that D1-grade and better veneers are likely to be marketable quality veneer. Adopting this assumption would further reduce the recovery values reported above, as no veneers in the grade quality analysis were rejected due to compression. Kumbyechants veneers would be most affected with $31 \%$ of veneers graded between D2-grade and D4 grade for compression, and therefore it would be rejected. Why Not and Elderslie veneers had similar proportions of veneer graded between D2-grade and D4-grade for compression (18\% and $21 \%$, respectively). Windermere had the least amount of veneer graded between D2-grade and D4 grade for compression at $2 \%$, which may be influenced by the smaller $\log$ size, and hence slower growth at this site.

With a variety of factors potentially influencing the presence of veneer compression, it is not possible to explain the result accurately. A probable contributor of the compression severity could be the log form (especially taper and sweep), which results in a veneer sheet containing a range of wood age (cambial age) due to the peeling process cutting parallel to the geometrical center of the tree, not parallel with the log surface.

McGavin et al. (2021). "Grade recovery of mahogany," BioResources 16(1), 1891-1913. 1905 
However, the proportion of veneers limited to D-grade due to compression did decrease as tree age increased (regression coefficient of $\mathrm{R}^{2}=0.85$ and P-value of 0.077) (Fig. 6). The reduced impact of veneer compression from the older logs may be a result of a higher proportion of veneers recovered from the log periphery that would contain more mature and less variable wood.

Further studies are critical to understand this phenomenon and to allow potential management strategies to be developed. It could be possible that the mechanism causing veneer compression may influence the level of distortion (twist, spring, and bow) in sawn boards.

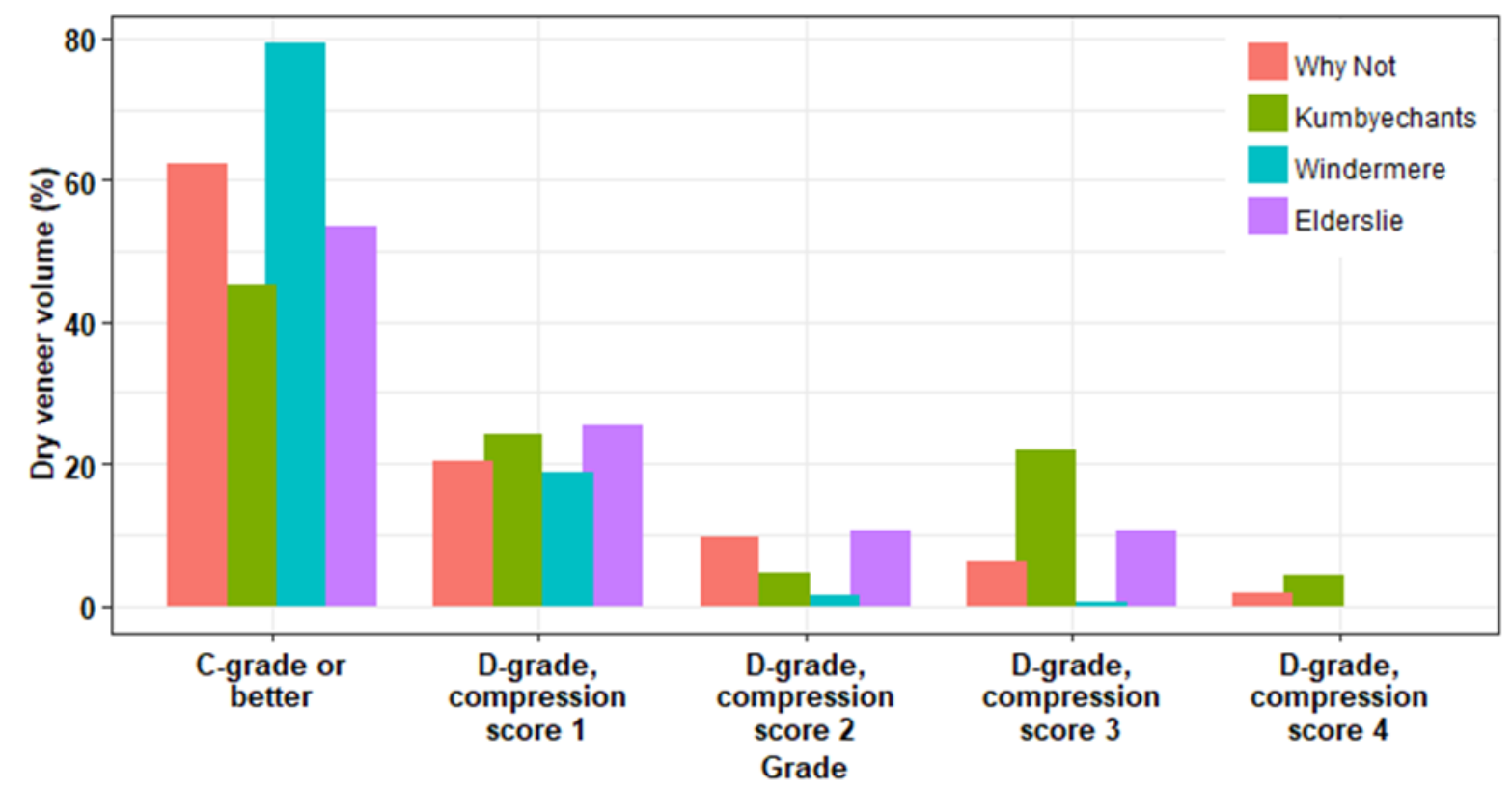

Fig. 5. Dry veneer volume recovery assessed based on veneer compression severity (ignoring all other defects in the veneer sheets)

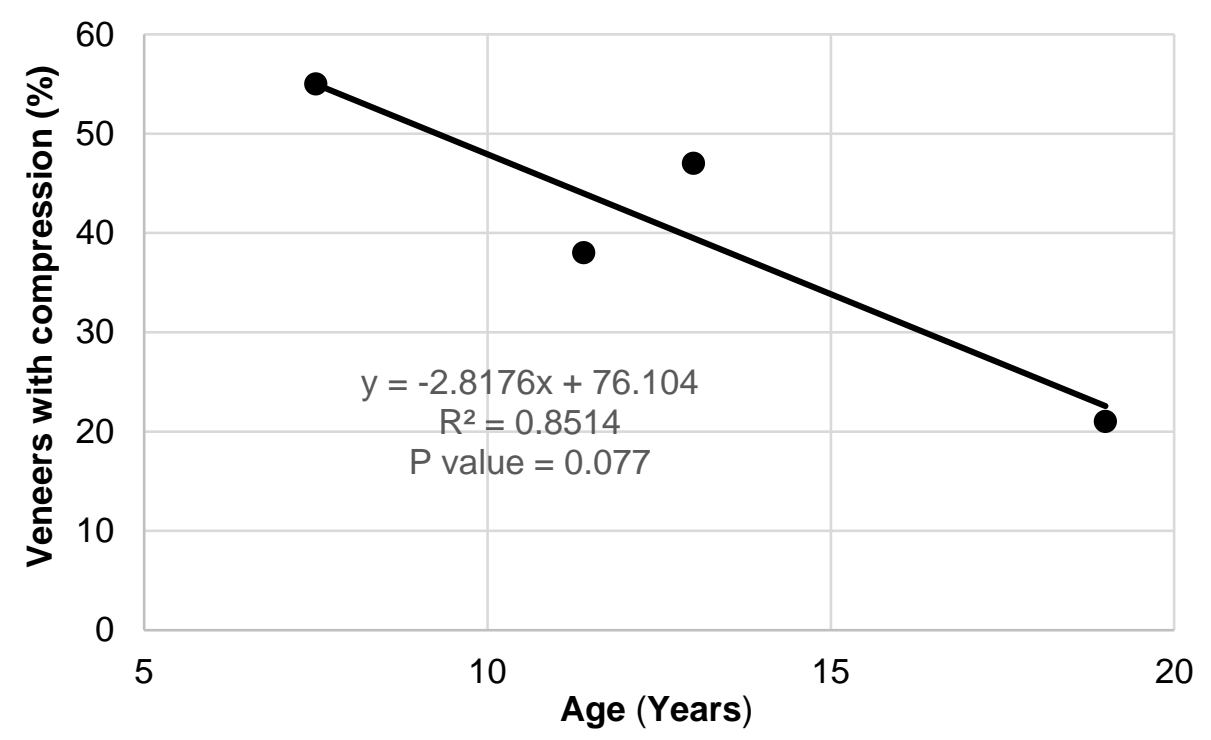

Fig. 6. Relationship between age (years) and the proportion of veneer downgraded due to compression for the four sites sampled for grade recovery assessment 


\section{Sawmilling}

Table 8 provides details of the various sawn timber recovery analyses undertaken. The sawn recovery focuses on the volume of square dimension boards recovered from the sawmilling process. Like dry veneer recovery, internal log defects are not considered at this point; therefore, log geometry (diameter and log form) predominately influences recovery. In addition, the potential recovery from sawing processes are more sensitive to changes in log diameters, especially as diameters decrease below $30 \mathrm{~cm}$.

Similar to the veneer processing results, the logs sampled from the Why Not plantation provided the highest recovery (49\%), benefiting from better log form. The lower than expected sawn recovery from the larger diameter Elderslie logs can be attributed to both an influence of $\log$ form, but additionally as a result of a higher proportion of $150 \mathrm{~mm}$ boards recovered from these larger logs compared to predominately $100-\mathrm{mm}$-wide boards recovered from the smaller logs from the other three sites. While the wider board width was compatible with the log center diameter, the log form (particularly taper) resulted in many boards containing wane on the board ends that negatively influenced the sawn recovery. However, the benefits were more visible post-grading, where $67 \%$ of the sawn recovery was recovered in graded boards, $10 \%$ more than the second ranked site (Why Not). Windermere provided a low sawn recovery, again, as a direct result of the negative and compounding influence of small-diameter logs and unfavorable log form.

While the sawn recoveries appear to be in line with traditional sawmilling production rates, the low $(<20 \%)$ recovery of sawn-dried-dressed boards highlights the well-recognised challenge of sawing relatively small diameter, young plantation hardwood logs (Leggate et al. 2000).

Table 8. Sawn Timber Recoveries

\begin{tabular}{|c|c|c|c|c|}
\hline & $\begin{array}{c}\text { Sawn Recovery } \\
\text { (\% of Log } \\
\text { Volume) }\end{array}$ & $\begin{array}{c}\text { Sawn Graded } \\
\text { Recovery } \\
\text { (\% of Log } \\
\text { Volume) }\end{array}$ & $\begin{array}{c}\text { Sawn Graded } \\
\text { Recovery } \\
\text { Percentage of } \\
\text { Dry Recovery } \\
\text { (\% of Dry Sawn } \\
\text { Volume) }\end{array}$ & $\begin{array}{c}\text { Sawn-dried- } \\
\text { dressed } \\
\text { Recovery } \\
\text { (\% of Log } \\
\text { Volume) }\end{array}$ \\
\hline Why Not & 49 & 30 & 57 & 20 \\
\hline Kumbyechants & 44 & 22 & 50 & 15 \\
\hline Windermere & 35 & 16 & 45 & 10 \\
\hline Elderslie & 40 & 26 & 67 & 19 \\
\hline
\end{tabular}

The Australian Standard AS 2796.2 (2006) provides grade criteria for three grades - select grade, medium feature grade, and high feature grade. Interestingly, the grade analysis resulted in identical grade recoveries when the sawn boards were graded independently to these three grades. That is, the sawn graded recovery and the sawn-drieddressed recovery values reflect the grade recovery for either select, medium feature, or high feature grade. Normally it would be expected that the recovered volume would decrease as the grade criteria increases (e.g., higher feature grade would be recovered compared to select grade). The main reason for this was the fact that defects present in the boards were those that have identical permissible limits across all three grades (e.g., wane, heart shakes, etc.).

Table 9 outlines the top 5 ranked defects that contributed to boards being rejected when assessed against AS 2796.2 (2006). Of the rejected board volume, the presence of wane accounted for the largest proportion across all four sites. The presence of wane in

McGavin et al. (2021). "Grade recovery of mahogany," BioResources 16(1), 1891-1913. 1907 
sawn boards is common and difficult to avoid when sawing small-diameter logs (Leggate et al. 2000; Walker 2006). The occurrence of wane increased as log form declined with increased taper, sweep, and fluting. Heart shakes and pith contributed to boards being rejected across all four sites. These defects originate from the center of the log (i.e., pith) or surrounding wood being included in sawn boards. The wood surrounding the pith (nominally within $50 \mathrm{~mm}$ radius of the pith) is often prone to heart shake splitting during drying. Wandering pith, a characteristic of plantation grown African mahogany that utilizes unimproved raw genetic stock increased the impact of these defects.

Table 9. Top 5 Ranked Defects Resulting in Boards Being Rejected

\begin{tabular}{|c|c|c|c|c|c|}
\hline \multirow{2}{*}{ Why Not } & \multicolumn{5}{|c|}{ Rank } \\
\cline { 2 - 6 } & $\begin{array}{c}\text { Wane } \\
(65 \%)\end{array}$ & $\begin{array}{c}\text { Heart shake } \\
(26 \%)\end{array}$ & $\begin{array}{c}\text { Pith } \\
(8 \%)\end{array}$ & $\begin{array}{c}\text { Want } \\
(1 \%)\end{array}$ & $\begin{array}{c}\text { End-split } \\
(<1 \%)\end{array}$ \\
\hline Kumbyechants & $\begin{array}{c}\text { Wane } \\
(69 \%)\end{array}$ & $\begin{array}{c}\text { Heart Shake } \\
(30 \%)\end{array}$ & $\begin{array}{c}\text { Pith } \\
(<1 \%)\end{array}$ & $\begin{array}{c}\text { End-split } \\
(<1 \%)\end{array}$ & - \\
\hline Windermere & $\begin{array}{c}\text { Wane } \\
(42 \%)\end{array}$ & $\begin{array}{c}\text { Heart Shake } \\
(39 \%)\end{array}$ & $\begin{array}{c}\text { Pith } \\
(12 \%)\end{array}$ & $\begin{array}{c}\text { Want } \\
(4 \%)\end{array}$ & $\begin{array}{c}\text { Decay Knot } \\
(4 \%)\end{array}$ \\
\hline \multirow{2}{*}{ Elderslie } & $\begin{array}{c}\text { Wane } \\
(37 \%)\end{array}$ & $\begin{array}{c}\text { Heart Shake } \\
(35 \%)\end{array}$ & $\begin{array}{c}\text { Decay Knot } \\
(19 \%)\end{array}$ & $\begin{array}{c}\text { Fractured } \\
\text { Knot } \\
(6 \%)\end{array}$ & $\begin{array}{c}\text { End-split } \\
(2 \%)\end{array}$ \\
\hline
\end{tabular}

As explained previously, the board distortion (twist, spring, and bow) analysis was undertaken independent of the grade analysis. The main reason for this, was the fact that the boards were 'phantom docked' as part of the grading process. Therefore, the board distortion could not be measured on the shortened 'in-grade' board length that would result after defect docking. Figures 7 to 9 illustrate the board distortion (twist, spring, and bow, respectively) when measured on the original board.

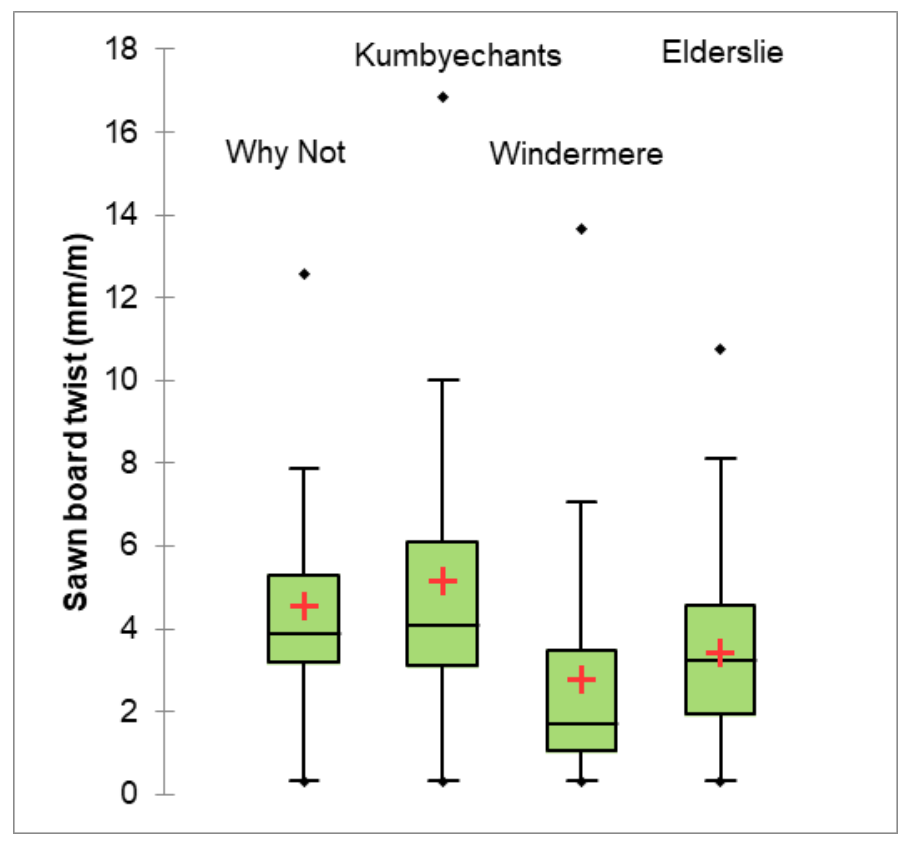

Fig. 7. Sawn board twist (Why Not $n=55$, Kumbyechants $n=57$, Windermere $n=36$, and Elderslie $n=69$ ) 


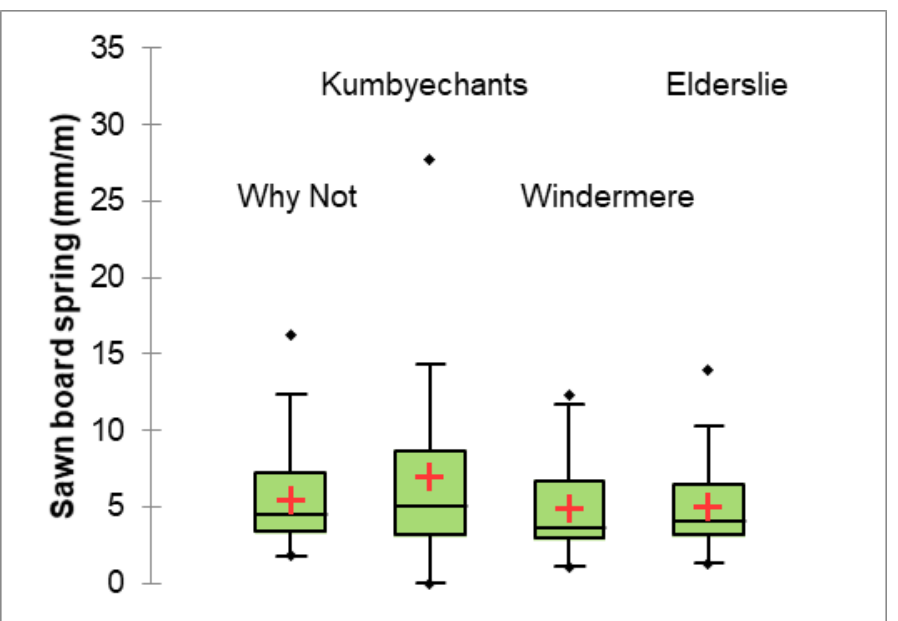

Fig. 8. Sawn board spring (Why Not $n=55$, Kumbyechants $n=57$, Windermere $n=36$, and Elderslie $n=69$ )

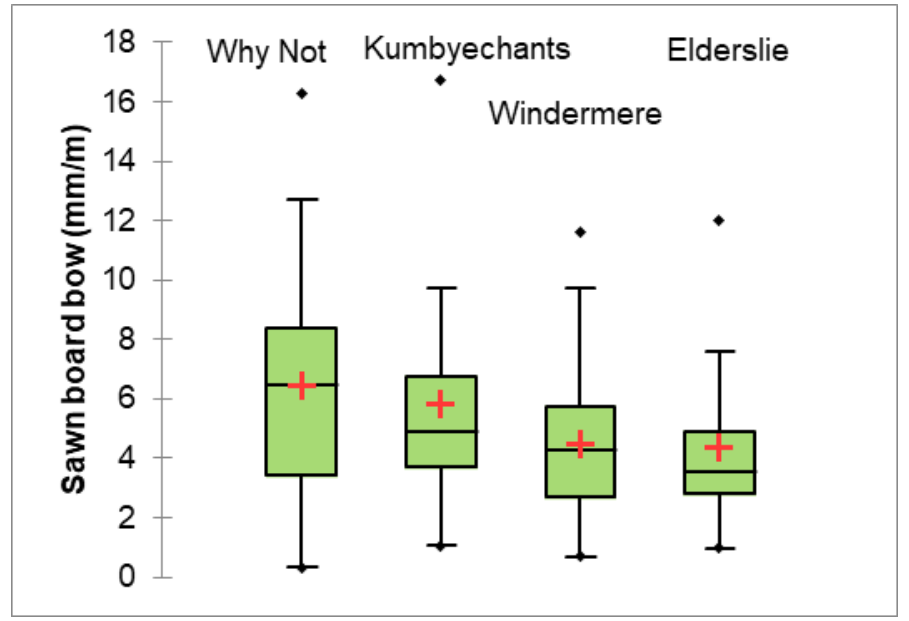

Fig. 9. Sawn board bow (Why Not $n=55$, Kumbyechants $n=57$, Windermere $n=36$, and Elderslie $n=69$ )

Australian standard AS 2796.1 (1999) outlines the sawn board distortion limits for several product groups. Table 10 outlines the impact of the distortion limits when applied to the sawn boards recovered from each of the four sites. All sites demonstrate the high presence of board distortion, which negatively impacts efficiency during processing along with product recovery. Table 10 includes a product example which African mahogany may target (strip flooring) and the analyses shows that less than $50 \%$ of the recovered boards would meet the distortion requirements of this product group when the requirements for twist, spring, and bow are combined. The Elderslie boards had only $10 \%$ of the recovered boards meeting the strip flooring distortion criteria. This potentially reflects the negative impact that high growth rate and relatively young harvest age can have on product quality. This is supported by the highest performing site being Windermere with $47 \%$ of boards meeting the strip flooring distortion criteria. The trees from this site were the oldest and the slowest growing. Further studies are critical to understand this phenomenon and to allow potential management strategies to be developed. It could be possible that the 
mechanism influencing distortion (twist, spring, and bow) in sawn boards may be influencing the compression in veneer.

Table 10. Board Distortion

\begin{tabular}{|c|c|c|c|c|}
\hline & Why Not & Kumbyechants & Windermere & Elderslie \\
\cline { 2 - 5 } & \% of boards that pass the AS 2796.1 & 1999) distortion allowance \\
\hline Twist & 40 & 33 & 72 & 64 \\
\hline $\begin{array}{c}\text { Spring - joinery, } \\
\text { dressed boards }\end{array}$ & 0 & 11 & 81 & 1 \\
\hline $\begin{array}{c}\text { Spring - light decking, } \\
\text { lining boards, etc. }\end{array}$ & 51 & 50 & 67 & 17 \\
\hline $\begin{array}{c}\text { Spring - strip flooring, } \\
\text { moldings }\end{array}$ & 80 & 73 & 81 & 83 \\
\hline $\begin{array}{c}\text { Bow - joinery, dressed } \\
\text { boards }\end{array}$ & 2 & 7 & 0 & 3 \\
\hline $\begin{array}{c}\text { Bow - strip flooring, } \\
\text { light decking, lining } \\
\text { etc. }\end{array}$ & 80 & 23 & 47 & 93 \\
\hline $\begin{array}{c}\text { Example: Strip flooring } \\
\text { (combines twist, } \\
\text { spring, and bow) }\end{array}$ & 15 & & & 10 \\
\hline
\end{tabular}

\section{CONCLUSIONS}

1. The four plantation sites sampled for process performance and product recovery assessment displayed very different ages and growth rates, reflected in the wide variation in log diameters. The variation in growth performance aligned well with the site's annual rainfall and was influenced by silviculture management. The logs used in the study contained log form characteristics, such as taper, sweep, and ovality, at levels above that expected from other plantation resources, which negatively affected product recovery rates. The variation in log form characteristics was much wider within sites than the variation in mean values between sites. There may be opportunities to reduce this wide variation through future selection and tree breeding programs that target more desirable tree form and properties.

2. Dry veneer recovery varied between sites and ranged between $56 \%$ and $73 \%$ of $\log$ volume. The variation can be generally explained by the variation in log diameter and log form characteristics (e.g., taper, sweep, and ovality). The Elderslie plantation logs yielded the highest gross recovery (63\% of log volume), attributed to the larger diameter and lower presence of internal log defects. Net veneer recoveries ranged between $42 \%$ and $55 \%$ for the four sites reflecting the proportion of log volume that could be potentially marketed.

3. The veneer grade recovery analysis showed that most of the recovered veneer failed to make a grade higher than D-grade, the lowest grade quality in accordance with AS/NZS 2269.0 (2012). The low recovery of higher grade veneers (C-grade and better), which are more suitable for face veneers, would make the commercial production of a standard mix of appearance veneer-based products challenging when only using a resource of this quality. The Windermere billets performed best with $37 \%$ of the net recovered veneers being $\mathrm{C}$-grade or higher $(24 \% \mathrm{C}$-grade and $13 \% \mathrm{~B}$ - 
grade). While the dry, gross, and net recoveries for this site were the lowest, with the potential to achieve higher grade qualities could be critically important to secure highvalue markets. Veneer compression (resulting in waviness), surface roughness, wane, and cumulative defects featured prominently as limiting veneer achieving grades higher than D-grade. Cumulative defects were the dominant reason for veneers failing to make any grade (i.e., reject).

4. The sawn recovery was in line with expectations, with $35 \%$ to $49 \%$ of log volume being achieved. However, the sawn graded recovery was low, with less than $30 \%$ of the log volume achieving a market grade quality (high feature, medium feature, or select grade in accordance with AS 2796.2 (2006) and less than $20 \%$ of the log volume recovered as boards that meet final market grade quality in a final product dimension. Defects, such as wane, heart shake, and pith, dominated the reason for boards being rejected. The presence of these defects were influenced by log form characteristics (e.g., large taper and sweep) with a high recovery of boards from the log central zone (nominally $50 \mathrm{~mm}$ radius of the pith) that were prone to checking or splitting during drying.

5. There was a high presence of compression observed in the recovered veneer sheets. While the market acceptance of African mahogany veneer with compression is yet to be tested, it is expected to have a negative impact on usability and potential value. With a variety of factors potentially influencing the presence of veneer compression, it is not possible to explain the result accurately. The proportion of veneers limited to D-grade due to compression did decrease as tree age increased.

6. The board distortion analysis highlighted the negative impact that twist, spring, and bow may have on the marketability of African mahogany sawn boards, depending on the target product specifications. The causes of board distortion may be linked to the phenomenon causing veneer compression. The phenomenon causing the compression in the veneer and distortion in the sawn boards is not well understood and may be influenced by genetics, growth cycles, log form characteristics (resulting in veneers or boards containing zones of different wood ages), wood structure (reaction wood), by processing protocols (e.g., lathe setup, pre-treatment conditions, etc.), or most likely, a combination of factors. A focused study to further investigate this phenomenon is critical to develop possible management strategies.

7. The comparable recovery of saleable product for each of the processing methods (net veneer recovery and sawn-dried-dressed recovery) demonstrated an advantage of veneer processing over sawing. Net veneer recovery ranged between 42 and $55 \%$ of log volume compared to 10 to $20 \%$ for sawn-dried-dressed recovery. While veneer processing was shown to be able to accommodate the small log diameters and other log features better than sawing, an economic analysis which includes processing costs, market prices and market demand for product are justified to support investment decisions.

\section{ACKNOWLEDGMENTS}

The authors are grateful for funding and support from the Forest and Wood Products Australia; along with African Mahogany (Australia) Pty Ltd. (AMA) and Huntley

McGavin et al. (2021). "Grade recovery of mahogany," BioResources 16(1), 1891-1913. 1911 
Management Limited, through their participation in the project. The Queensland Government, Department of Agriculture and Fisheries (DAF), and McGrath Forest Services Pty Ltd. are acknowledged for supporting the project.

The industry research group supported the study through the identification of suitable trees, harvesting and transport of the logs to the DAF Salisbury Research Facility, along with providing the plantation history and silvicultural details for the sample sites. This input was provided in the Northern Territory by Adeline Armougom and Frank Miller from AMA, and Rob Tap from Forestfarmer Pty. Ltd. In Queensland, the trial history and logistical support for the harvesting and transport was provided by Malcolm Cleland, John Gillman, Peter Gillman, and Ian Knobel from Huntley Management Services. Access to the Farm Forestry thinning trial at Windermere, Bowen was provided by the owners Dr. Tony Mallet and Julie Baxter and is gratefully acknowledged. Without the efforts of Geoff Dickenson, Nick Kelly, David Lee (from DAF), and Alex and Angela Lindsay (Forsite Forestry and previously DAF) in establishing, maintaining, and measuring the thinning trial at Bowen, this resource would not have been available to the project.

The DAF research team at the Salisbury Research Facility and in particular Xavier Murray, Eric Littee, Rica Minnet, and Daniel Field are acknowledged for their contribution to the log, process, and grade quality components of the project. The support provided by DAF through the provision of the unique facilitates located at the Salisbury Research Facility is acknowledged as critical to facilitate processing and product studies of this nature.

\section{REFERENCES CITED}

Armstrong, M., Reilly, D. F., Lelieve, T., Hopewell, G., Redman, A., Francis, L., and Robertson, R. M. (2007). Evaluation of the Wood Quality and Potential Use of Plantation Grown Khaya senegalensis (African Mahogany) (RIRDC Publication No. 07/107), Rural Industries Research and Development Corporation, Canberra, Australia.

AS 2796.1 (1999). "Timber - Hardwood - Sawn and milled products - Product specification," Standards Australia, Sydney, Australia.

AS 2796.2 (2006). "Timber - Hardwood - Sawn and milled products - Grade description," Standards Australia, Sydney, Australia.

AS/NZS 2269.0 (2012). "Plywood-structural, Part 0: Specifications," Standards Australia, Sydney, Australia.

Dickinson, G. R., Fremlin, R., Nikles, D. G., Reilly, D., Huth, J. R., and Lee, D. J. (2009). "Enhancement of tree improvement and conservation outcomes with Khaya senegalensis (African mahogany) through base population development and expansion in Australia," in: Australasian Forest Genetics Conference, Forest Products Commission, Perth, Australia, pp. 27.

Leggate, W., Palmer, G., McGavin, R., and Muneri, A. (2000). "Productivity, sawn recovery and potential rates of return from eucalypt plantation in Queensland," The Future of Eucalypts for Wood Products Conference, Launceston, Tasmania, pp. 228239.

McGavin, R. L., Bailleres, H., Lane, F., Blackburn, D., Vega, M., and Ozarska, B. (2014a). "Veneer recovery analysis of plantation eucalypt species using spindleless lathe technology," BioResources 9(1), 613-627. DOI: 10.15376/biores.9.1.613-627

McGavin et al. (2021). "Grade recovery of mahogany," BioResources 16(1), 1891-1913. 1912 
McGavin, R. L., Bailleres, H., Lane, F., Fehrmann, J., and Ozarska, B. (2014b). "Veneer grade analysis of early to mid-rotation plantation Eucalyptus species in Australia," BioResources 9(4), 6562-6581. DOI: 10.15376/biores.9.4.6562-6581

McGavin, R. L., Bailleres, H., Hamilton, M., Blackburn, D., Vega, M., and Ozarska, B. (2015a). "Variation in rotary veneer recovery from Australian plantation Eucalyptus globulus and Eucalyptus nitens," BioResources 10(1), 313-329. DOI: 10.15376/biores.10.1.313-329

McGavin, R. L., Bailleres, H., Fehrmann, J., and Ozarska, B. (2015b). "Stiffness and density analysis of rotary veneer recovered from six species of Australian plantation hardwoods," BioResources 10(4), 6395-6416. DOI: 10.15376/biores.10.4.6395-6416

McGavin, R. L., and Leggate, W. (2019). "Comparison of processing methods for small diameter logs: Sawing versus rotary peeling," BioResources 14(1), 1545-1563. DOI: 10.15376/biores.14.1.1545-1563

Nikles, D. G., Bevege, D. I., Dickinson, G. R., Griffiths, M. W., Reilly, D. F., and Lee, D. J. (2008). "Developing African mahogany (Khaya senegalensis) germplasm and its management 129 for a sustainable forest plantation industry in northern Australia progress and needs," Australian Forestry 71(1), 33-47. DOI:

10.1080/00041158.2008.10676269

Nikles, D. G. (2006). "The domestication of African mahogany (Khaya senegalensis) in northern Australia," Australian Forestry 69(1), 68-69. DOI:

10.1080/00049158.2006.10674989

Queensland Government (2020). "Australian climate data from 1889 to yesterday," (https://legacy.longpaddock.qld.gov.au/silo/), Accessed 7 June 2018.

Reilly, D. F., Robertson, R. M., Nikles, D. G., Robson, K., and Lee, D. J. (2007). Testing and Breeding Forest Trees for Plantations in the Northern Territory (RIRDC Publication No. 07/113), Rural Industries Research and Development Corporation, Canberra, Australia.

Venn, T. J., McGavin, R. L., and Ergashev, A. (2020). "Accommodating log dimensions and geometry in log procurement decisions for spindleless rotary veneer production," BioResources 15(2), 2385-2411. DOI: 10.15376/biores.15.2.2385-2411

Walker, J. C. (2006). Primary Wood Processing: Principles and Practice, Springer Science \& Business Media, Heidelberg, Netherlands.

Zbonak, A., Brown, T., Harding, K., Innes, T., and Davies, M. (2010). Wood Properties and Processing Outcomes for Plantation Grown African Mahogany (Khaya senegalensis) Trees from Clare, Queensland (18-and 20-year-old) and Katherine, Northern Territory (14-year old) (Unpublished Report), Department of Employment, Economic Development and Innovation, Queensland Government, Queensland, Australia.

Article submitted: September 21, 2020; Peer review completed: December 5, 2021;

Revised version received and accepted: January 21, 2021; Published: January 26, 2021.

DOI: 10.15376/biores.16.1.1891-1913 